\title{
Music Teaching of Overseas Russian in Heilongjiang in the Early Twentieth Century
}

\author{
Qi Wang \\ Heihe University \\ Heihe, China
}

\begin{abstract}
In the beginning of the 20th century, with the opening of Middle East Railway, a batch of modern cities and towns sprung up on the earth of Longjiang because of railway, especially the central pivot of the Middle East Railway - Harbin which quickly became an internationalized city: railways traversed Europe and Asia and extended in all directions with convergence and flow of physical distribution and information; Because of the inburst of nearly 200,000 expatriates, the degree of internationalization could be abreast of Moscow, having created a miracle during the urbanization process in modern China. Known as the reputation of "Oriental Moscow" and "Oriental little Paris", Harbin draws on the European music culture, where there are China's first music school and the first ballet over the same period of Shanghai. Foreign cultural elements like overseas Russian culture and others merge with each other, forming education and culture of Harbin that has the unique international convergence characteristics. The culture that all rivers run into sea and wide heart embraces all have been branded for Harbin and even Heilongjiang by these cultural elements and immigrant culture from the mainland.
\end{abstract}

Keywords—overseas Russian; Heilongjiang; music

\section{INTRODUCTION}

Affected by the Middle East Railway and "the October Revolution", the Russians began to immigrate to northeast China and a large number of Belarusian troops gathered in Harbin from Blagoveshchensk (Hailanpao), Vladivostok (Vladivostok) and Chita. "The total number of overseas Russian in the whole of the Middle East Railway dependent territory is 73,635", the Far East News (Official newspaper of Middle East Railway Company) reported on July 21, 1911. According to the "Harbin Local Chronicles", in 1922 the number of Russian immigrants in Harbin amounted to 155,402 . And in accordance with the statistics from Russian scholars, the number of overseas Russian settled in Harbin in 1923 was at one time as many as 200,000 people and even exceeded the number of local Chinese residents, so Harbin became the China's largest overseas Russian compact community center. In their own words, at the beginning of 1920, when an overseas Russian just arrived in Harbin, he did not feel that he stayed abroad. [1] In the beginning of the twentieth century, Harbin, the central pivot of the Middle East Railway, was known as "Oriental Moscow" and "Oriental little Paris", which was the modern city and town sprung up by the railway and quickly became a internationalization immigrant city that has cultural diversity.

\section{RUSSIAN MUSIC TEACHING SYSTEM IN HARBIN INTRODUCED BY OVERSEAS RUSSIAN}

The Russian pays close attention to education and the majority of overseas Russian in Harbin has higher cultural quality. At the beginning of the twentieth century, education system of overseas Russian in Harbin and education system before "the October Revolution" have been carried through step by step. The complete education system is constituted by primary schools, middle schools (also divided into ordinary secondary schools and Christian middle schools), vocational schools and the institutions of higher learning, also embodying on the aspect of teaching materials, school system and others at the same time. The descendants of the overseas Russian are also benefited from this step-by-step educational method.

Due to the preference of art of music, at the time setting foot into China, the overseas Russian brought systematic and normative western music educational pattern into Harbin. Overseas Russian musicians set up conservatories and training classes in the place of residence for education and practice. In order to meet the music needs of the children of the overseas Russian, in May 1921, the first professional music school of Harbin - "the first Harbin Conservatory of Music" was established. The school gave instruction in accordance with the outline of the Moscow Music Association with wellestablished subjects and the teaching plans that was in line with the idea of cultivating music talents, which mainly taught courses like piano, violin, cello, copper pipe, wooden pipe, vocal music, harmonics, instrumental ensemble, opera, figure, playing, records, music theory, solfeggio and ear training, music principle and others. In July 1925, the higher music school which was named after the famous Russian composer and conductor Glazunov - "Harbin Glazunov Higher Music School" was established with the courses like Cello, violin, double bass, piano, music history, vocal music, solo, bassoon, clarinet, oboe, flute, trumpet, French horn, percussion music, Italian, duet, chorus, art history, opera, music theory, accordion and so on. October 20,1927, the third music school - "Harbin music training class" was set up, which mainly taught courses like vocal music, piano, violin, cello, vocal music chorus, church choral, choral conductor, accordion and other courses. [3] In addition, there were some private music schools. Through the establishment of these music schools, 
people in Harbin knew of the "foreign music" and improved the musicianship.

\section{The MUSIC TEACHING EXPERIENCES OF OVERSEAS RUSSIAN}

The overseas Russian musician who has the considerable influence on teaching of Harbin is В. Л. Трахтенберг who is undoubtedly veteran music educator and concert performer musician. He graduated from St. Petersburg Conservatory, came to Harbin in 1922, and acted as chief violin of "Ha Xiang" philharmonic society since 1930s and served as art committee chairman in Harbin first higher music school in 1933. As living in Harbin for long time, he had prominent status and high reputation. He has taught lots of students, including many Chinese children who learnt violin and other musical instruments and were the members of China first generation musicians. He still teaches his students with teaching methods in his own country. He lays emphasis on basic skills training, so he requires students to exercise longtones of open strings long time from the beginning of the day, which is the premise of playing. After a period of time, students are asked to gradually touch a variety of major scale and minor scale, arpeggio, diphonia and others and then begin to exercise the etudes, musical composition and other contents until he thinks that you could continue to learn new contents. He believes that these rigorous trainings are the only way for them to become professional students in the future. В. Л. Трахтенберг is deeply loved by students, as they can quickly grasp his teaching thought and master the technology essentials- from shallow to deep to integrate into the production. During the learning process, the teacher and students will have a good exchange. For production that students exercise, he could play with the piano regardless of sizes to emphasize the wrong notes during the process of practice, so that students can be clear at a glance. As for the intonation problem (especially the "diphonia"), he advocates listening and exercising with the tonal intonation, which greatly improve the accuracy when playing "diphonia". В. Л. Tрахтенберг has various teaching methods and whistle playing method has gotten recognition from students. He can accurately play all musical intervals and half-steps with whistle with plentiful, flexible and diverse classroom form.

At the beginning of the 20th century, the overseas Russian musicians Pogodin, Yijia Tebel, Dimitrov and Sidorov who teach violin in Harbin were very famous.

It is unique for the training of basic skills and the method of improving technical ability from Violinist Sidorov overseas Russian musicians. In the process of exercise, it focuses on tension of the left hand finger and elasticity training. Fingers raise and then straighten to form motion curves with cycle repeated and the effect is obvious. "Rubbing string and vibrato" from Sidorov, which is different from "rubbing string and vibrato" of the violin that takes trill from wrist and finger as the principal thing, takes vibration as the principal thing with greater movement, playing full-bodied tone. In 1949, Chinese student Deng Lizhong of В. Л. Трахтенберг in the business affairs club of Dao $\mathrm{Li}$ held a chamber concert in which his students Ivanov, Kovalev and Chernoff admiring him played "Vagrancy", "Spanish Dance" and other production.
Trumpet concert performer Guzinkov - overseas Russian musicians have professional courses for students using the thick teaching material called "Arban Trumpet Tutorial" and took demonstration and playing as the principal thing in the "Jianke"(now called "Huike") for Chinese students. Because his Chinese was not very good, so demonstration and playing were the main way during his teaching from cover to cover. In the process of "Listening the Playing", students compared and imitated in order to accurately keep a keen eye on the grasp of music sense and phrases handling. In 1955, Guzinkov held a personal trumpet solo concert in the business affairs club of Dao Li and played the "The Song of Napoli" and others, which was very popular.[3]

The Polish contrabass player B.F.Svenchitzky, who was from contrabass training class, was contrabass player of Harbin Symphony Orchestra and deeply respected by overseas Russian musicians. Wang Xinmin who was the student of his in those years and the contrabass grand old man in Heilongjiang Province said that when B.F.Svenchitzky had classes in the former Soviet Union higher music school in Yi Zhou street of Nangang, all teachers in this school represented by the school president Oksakovsky needed kiss his hand for salute as seeing him, which expressed the reverent and respectful attitude. In the 1950s, he taught Chinese students Wang Xinmin piano (later known as "Double Bass Wang"), using the Russian version "Schucco Contrabass Tutorial". In the teaching, he had the rigorous attitude and advocated that the ability of the joint at the root of the left hand finger buckled strings with slight movements and fast speed to make musical composition playing flexible and unique.

These overseas Russian musical educators paid close attention to the combination of theory and practice. They often organized their own students to performances in the railway club, also intensified the students' chamber music training in ensemble play training courses and during daily teaching, increased the proportion of sonata production aiming at training subjects of individual basic skills. Overseas Russian artists all actively participated performance, demonstrating their talents on the stage and incisively and vividly showed the students the difficult points of teaching at ordinary times through on-the-spot performance to not only improve their interests in music but also greatly promote the improvement of school teaching achievement.

\section{THE TEACHING CHARACTERISTICS OF OVERSEAS RUSSIAN}

Overseas Russian educators in teaching varied with each individual and acted according to actual circumstances. They did not completely follow the outline and Syllabus of Russian Royal College of Music but taught students according to their aptitude. On the aspect of vocal music teaching, they attached great importance to the basic knowledge and ability training of singing, beginning from the lower grades. Production from Rossini, Donizetti and others, which were European classical music artistic work, were largely avoided pomposity of onesided pursuit of vocal music technique and voice skills, emotional expression and style show were entirely integrated into vocal music art. In line with fundamentally enhancing entire and full-scale musicianship and basis-oriented teaching 
idea of the teachers and students of vocal music to vocal music art, choices and use of teachers to teaching tracks showed a higher flexibility. According to the requirements of the outline and the assignment of teaching tasks of each semester, the teacher firstly decided on range and then students were free to choose which tracks to learn according to their own interests, which greatly enhanced the students thirst for knowledge (changing the passive imbuement to active acquisition of knowledge) and laid a solid foundation for future work and practice. At the same time in line with creativity, subjectivity and personal specialty, teachers constantly and simultaneously updated teaching content and increased knowledge reserves. The professional piano accompaniment teacher should have in the class. The vowel was firstly used for exercising sound production and thoracoabdominal joint breathing was emphasized, so that Kaikouyin (When pronouncing, the mouth is open) and Bikouyin (When pronouncing, the mouth is close) were uniform. Then it began to sing the songs. According to the background of the songs, teachers did the demonstration with luxuriant voice and sensibility to achieve the resonance of skills, emotions and style. During the 20th century, Russian vocal music education took the leading position in the world vocal music art system, which was closely associated with dense musical and cultural atmosphere and scientific teaching philosophy in their own country, not only respecting the traditional norms but also completing innovation and development with rigorous and open attitude.

\section{CONCLUSION}

St. Petersburg Conservatory of Music and the Moscow Conservatory of Music, as the beginning of Russian classical music, have fostered the musical temperament of the Russian nation and have a wide-ranging and far - reaching influence on Chinese music in the early twentieth century. Since modern time of China society, overseas Russian had been occupied in musical education activities in Harbin named the "capital" in China outside of Russian territory, serving as a cultural envoy to promote the spread of western music in Harbin with the introduction of western learning to the east; Chinese musicians trained by overseas Russian in Harbin were all over the country and strengthened domestic musical and cultural strength with their high level and high-quality professional level, promoting Sino-Russian cultural exchange and deepening mutual understanding and friendly cooperation between two peoples to a certain extent. [2] The affinity of Russian music is closer to that of Chinese music. It is also the music of the oriental people. On the aspects of music development and education and teaching, Sino-Russian music could learn from each other and integrate with each other, which has capacious development space.

\section{REFERENCES}

[1] Li Meng. The missing link: literature of Russian nationals in China [M]. Beijing: Peking University Press, 2007: 13.

[2] Liu Xinxin, Liu Xueqing. Harbin Western Music History [M]. Beijing: People's Music Publishing House, 2002.

[3] Shi Fang, etc. Harbin Overseas Russian History [M]. Harbin: Heilongjiang People's Publishing House, 2003: 605. 